\title{
Evaluation approaches of sludge ultrasonic pretreatment efficiency: a review
}

- Le Ngoc Tuan

University of Sciences, VNU-HCM

- Pham Ngoc Chau

Bangkok University - Thailand

(Manuscript Received on October $08^{\text {th }}$, 2012, Manuscript Revised December $10^{\text {th }}$, 2013)

\begin{abstract}
:
Ultrasonic irradiation (US) is a feasible and promising mechanical disruption technique for sludge disintegration, biodegradability acceleration, and anaerobic digestion enhancement. It is clear that many processing factors significantly affect cavitation and consequently the efficiency of sludge pretreatment. Therefore, assessment,

comparison, and selection of optimal ultrasonic conditions for actual application of sludge pretreatment are sorely necessary. The objective of this work is to present an extensive review of evaluation approaches of sludge ultrasonic pretreatment efficiency based on physical, chemical, and biological properties of sludge.
\end{abstract}

Keywords: Biological change-based evaluation, chemical change-based evaluation, evaluation approaches, physical change-based evaluation, ultrasonic pretreatment, waste activated sludge.

\section{INTRODUCTION}

Incineration, ocean discharge, land application and composting are the common sludge treatments used over the years but no longer reliable due to the economic difficulties and their negative impacts on environment. Therefore, anaerobic digestion (AD) of sludge has applied as an efficient and sustainable technology for sludge treatment thanks to mass reduction, odor removal, pathogen decrease, less energy use, and energy recovery in form of methane.

The AD of sludge is a complex and slow process requiring high retention time to convert degradable organic compounds to $\mathrm{CH}_{4}$ and $\mathrm{CO}_{2}$ in the absence of oxygen through four stages: hydrolysis, acidogenesis, acetogenesis, and

methanogenesis. Hydrolysis is known as a ratelimiting step, in which the intracellular biopolymers solubilize and convert to the lower molecular weight compounds of sludge. This low rate of microbial conversion requires the pretreatment of sludge, which ruptures the cell wall and facilitates the release of intracellular matter into the aqueous phase to accelerate biodegradability and to enhance the AD.

There are some very popular techniques used in sludge pretreatment such as biological, thermal hydrolysis, mechanical, and chemical methods. Biological technique provides a moderate performance increase over mesophilic digestion with moderate energy input. Thermal hydrolysis $\left(>100^{\circ} \mathrm{C}\right)$ provides a significant increase in

\section{Trang 68}


performance with a substantial thermal energy consumption. Mechanical treatment methods (ultrasonic pretreatment, lysis-centrifuge, liquid shear, grinding...) provide a moderate performance improvement with moderate electrical input. Chemical treatment methods (oxidation, alkali, acidic pretreatment...) are also applied in sludge pre-treatment [1].

As cited by Pilli et al. [2], ultrasonic irradiation (US) is a feasible and promising mechanical disruption technique for sludge disintegration and microorganisms' lyses according to the treatment time and power, equating to specific energy input. Several positive characteristics of this method are efficient sludge disintegration [2], improvement in biodegradability and bio-solids quality [3], increase in biogas/methane production $[3,4,5]$, no chemical additives [6], less sludge retention time [7], and sludge reduction [5].

The mechanisms of ultrasonic sludge disintegration are (a) Hydro-mechanical shear forces created by cavitation, (b) Oxidizing effect of $\mathrm{OH}, \cdot \mathrm{H}, \cdot \mathrm{N}$, and $\mathrm{O}$ produced under the ultrasound radiation, (c) Thermal decomposition of volatile hydrophobic substances in the sludge, and (d) Increase in temperature during ultrasonic activated sludge disintegration. It was proved that sludge disintegration is mainly caused by hydromechanical shear forces and by the oxidizing effect of $\mathrm{OH}$, but mostly in the former process [2].

The ambient conditions of the reaction system can significantly affect the intensity of cavitation; consequently affect the efficiency (rate and/or yield) of reaction. Different conditions resulted in different effectiveness of sludge ultrasonic pretreatment. Main parameters effecting cavitation include ultrasonic frequency, power input, and intensity, temperature, hydrostatic pressure, stirrer type and speed, and sludge characteristics (sludge type, pH, total solid content TS...)

The objective of this work is to present an extensive review of evaluation approaches of sludge ultrasonic pretreatment efficiency based on physical, chemical properties, and biological properties, serving assessment, comparison, and selection of optimal conditions for actual application.

\section{PHYSICAL CHANGE-BASED EVALUATION OF SLUDGE ULTRASONIC PRETREATMENT EFFICIENCY}

Physical properties used for evaluation of sludge ultrasonic pretreatment efficiency usually include: particle size reduction, sludge mass reduction, dewaterability, settle-ability, turbidity of sludge, and microscopic examination.

\subsection{Particle size reduction}

Ultrasonic pretreatment is very effective in reducing the particle size of sludge, which is analyzed by different techniques (sieves, sedimentation, electric-ozone sensing, microscopy, laser diffraction, in which the last is usually used). The efficiency of size reduction depends on (i) US density, (ii) US duration, (iii) US power input ( $\left.\mathrm{P}_{\mathrm{US}}\right)$, (iv) specific energy input (ES), and (v) sludge characteristics.

(i) The mean particle size reduction increases with the increase in US density [2], 60\% and 73\% at $2 \mathrm{~W} / \mathrm{mL}$ and $4 \mathrm{~W} / \mathrm{mL}$, respectively [6], which means sludge disintegration efficiency also increases at higher US densities. At $10 \mathrm{kWh} / \mathrm{kg}_{\mathrm{TS}}$, particle size was reduced from $49 \mu \mathrm{m}$ to $19 \mu \mathrm{m}$, $13 \mu \mathrm{m}$, and $9 \mu \mathrm{m}$ corresponding to the US density of $0.18 \mathrm{~W} / \mathrm{mL}, 0.33 \mathrm{~W} / \mathrm{mL}$, and 0.52 $\mathrm{W} / \mathrm{mL}$, respectively [8].

(ii) The particle size reduces gradually owing to the increase in US duration [7, 8], but beyond a sonication period of $10 \mathrm{~min}$, the particle size has a reverse trend [9] due to re-flocculation of the particles. However, this phenomenon was not recorded in a series of researches by Show et al. 
[8] and Le et al. [10] even after $20 \mathrm{~min}$ and 117 min of sonication, respectively. The authors indicated that sludge particles were disrupted very fast, especially in the initial period of ultrasonic process, and much faster than COD release in the aqueous phase.

(iii) Low US power input has no effect on floc size reduction and the floc size reduction increases with the increase in $\mathrm{P}_{\text {Us. However, }}$ there has an optimum $\mathrm{P}_{\mathrm{US}}$ and US duration for sludge disintegration because floc will be completely destroyed after 60 min of sonication despite a further increase in $\mathrm{P}_{\mathrm{US}}$ or US duration [11].

(iv) A specific energy input of $1000 \mathrm{~kJ} / \mathrm{kg}_{\mathrm{TS}}$ may be the disruption threshold of floc [12]. Following the increase in ES, US has caused a decrease in particle size gradually [9], [13]. Particle size was inversely proportional to energy dosage $(R=-0.996$ at the 0.01 significance level $)$ [12].

Particle size distribution of waste activated sludge (WAS) in the range of $0.4 \mu \mathrm{m}$ to $1000 \mu \mathrm{m}$ was investigated under $20 \mathrm{kHz}$ US frequency at different ES. The findings of Bougrier et al. (2005) cited by Pilli [2] showed that the volume occupied by particle sizes of less than $1 \mu \mathrm{m}$ has increased with an increase in ES: from $0.1 \%$ of the raw sample to $1.5 \%$ of the pretreated sludge at ES of $14550 \mathrm{~kJ} / \mathrm{kg}_{\mathrm{TS}}$. The similar trend was recognized with particles larger than $100 \mu \mathrm{m}$ due to re-flocculation [9]. According to El-Hadj et al. (2007) cited by Pilli [2], with an increase in ES, the volume occupied by the smaller particle size $(\leq 28 \mu \mathrm{m})$ was more than $90 \%$.

Particle size distribution was also carried out with sludge particles smaller than $100 \mu \mathrm{m}$ in diameter [12]. The dp90 \& D[4,3] of sludge decreased from $77.05 \& 40.49 \mu \mathrm{m}$ (raw sludge) to $75.77 \& 39.79 \mu \mathrm{m}$, and $55.06 \& 27.54 \mu \mathrm{m}$ corresponding to an increase in ES from 0 to 500 and $26000 \mathrm{~kJ} / \mathrm{kg}_{\mathrm{TS}}$, respectively. Compared to the raw sludge, at ES below $1000 \mathrm{~kJ} / \mathrm{kg}_{\mathrm{TS}}$, the decrease in dp90 was very slight $(3.2 \%)$; however, at $26000 \mathrm{~kJ} / \mathrm{kg}_{\mathrm{TS}}$, the dp90, dp75, dp50, and dp 25 decreased by $28.5 \%, 31.8 \%, 34.2 \%$, and $37.6 \%$, respectively, which indicated that different particle size distributions have (slightly) different reduction extents, in which small particles were disrupted more effectively by US than larger ones [12].

Another research showed that "micro"-flocs ( $<4.4 \mu \mathrm{m}$, having strong binding forces) have less susceptibility to sonication than "macro"-flocs ( $>4.4 \mu \mathrm{m}$, having larger surface area exposing to sonication). In other words, the latter showed more disruption possibility than the former [8], which was in agreement with [2, 12, 14]. The terms "micro" and "macro" used in this case are different from the ones used in The Floc Structure Model of Jorand et al. [15]: the predominant macro-flocs $(125 \mu \mathrm{m})$ were formed from $13 \mu \mathrm{m}$ micro-floc aggregates made up of smaller particles $(2.5 \mu \mathrm{m})$. Chu et al. (2001) [11] showed that the sludge floc consists of primary particles $(\sim 2 \mu \mathrm{m})$, micro-flocs $(\sim 13 \mu \mathrm{m})$, and highly porous flocs $(\sim 100 \mu \mathrm{m})$.

(v) According to Chu et al. (2002) cited by Pilli [2], with regard to sludge type, the particles of flocculated sludge in AD reduced more than $50 \%$ in size after sonication compared to those of raw sludge. Similarly, within $20 \mathrm{~min}$ of sonication, the disintegration was more significant in secondary sludge $(85 \%)$ than in primary sludge $(71 \%)$ because the former contains mostly biomass (microbial cells) whereas the latter mainly consists of settle-able solids (containing fibers and less degradable cellulosic material) [6].

With regard to TS concentration of sludge, after sonication, the size reduced more in lower TS sample: $\mathrm{d}_{50}$ of sludge with $2 \%$ TS decreased by 6.5 fold at $0.67 \mathrm{~W} / \mathrm{mL}$; higher TS concentrations (4\% and $6 \%$ ) require more US 
density $(0.83 \mathrm{~W} / \mathrm{mL}$ and $1.03 \mathrm{~W} / \mathrm{mL}$, respectively) to gain the same level of particle size reduction [16].

In short, ultrasonic pretreatment significantly decreases the particle size of sludge, especially in the very short time of sonication. Sludge particle size reduction is sometimes used to assess the degree of sludge disintegration. Although this reduction accelerates the hydrolysis stage of sludge $\mathrm{AD}$ and enhances degradation of organic matters, the findings of Muller et al. (2004) cited by Dogan [17] indicated this parameter not to be convenient for process optimization.

\subsection{Sludge mass reduction and mass composition}

The sludge mass reduction is usually measured by the decrease in the suspended solid (SS) concentration. After sonication, the ratio of $\mathrm{SS}$ reduction was lower than that of VS reduction, which implied the inorganic matters (considered as the difference between total solids TS and volatile solids VS) were stable in US process $(2410 \mathrm{mg} / \mathrm{L}$ after $30 \mathrm{~min}$ of sonication compared to the initial inorganic of $2560 \mathrm{mg} / \mathrm{L}$ ). The sludge mass reduction was mainly from liquefaction of the organic matters. During US (0-30 $\mathrm{min})$, SS reduction and VS reduction increase were almost linear with US duration, which indicated the continuous and stable sludge floc disintegration, mass reduction, and cell lysis: $\mathrm{SS}$ reduction $(\%)=0.875 \mathrm{x}$ US duration $(\mathrm{min}), \mathrm{R}$ $=0.98[18]$.

Others parameters used to assess the sludge reduction due to US, subsequent the efficiency of sludge ultrasonic disintegration, were the solubilisation of TS and VS:

$$
\begin{aligned}
& \mathrm{S}_{\mathrm{TS}}= {\left[\left(\mathrm{TS}_{0}-\mathrm{TS}\right) / \mathrm{TS}_{0}\right] \times 100 \% } \\
& \mathrm{~S}_{\mathrm{VS}}=\left[\left(\mathrm{VS}_{0}-\mathrm{VS}\right) / \mathrm{VS}_{0}\right] \times 100 \%
\end{aligned}
$$

where TS and VS were measured on the total sludge.
The solubilisation of $\mathrm{TS}\left(\mathrm{S}_{\mathrm{TS}}\right)$ increased linearly following an increase in ES (from 3600 to $108000 \mathrm{~kJ} / \mathrm{kg}_{\mathrm{TS}}$ ) and reached $14.65 \%$ at $\mathrm{ES}_{\max }$. Initially, the VS solubilisation $\left(\mathrm{S}_{\mathrm{VS}}\right)$ increased fast in the ES range of $0-31500 \mathrm{~kJ} / \mathrm{kg}_{\text {TS }}$ (reached $15.8 \%)$ and then slowed down at higher ES values (reached $23 \%$ at $\mathrm{ES}_{\max }$ ) [20]. The main purpose of sludge disintegration is to transfer organic matters from the solid to the aqueous phase. The increase in soluble organic could be correlated with the VS reduction (because both COD and VS represent the organic matters of sludge). A higher $\mathrm{S}_{\mathrm{VS}}$ is important for eliminating/shortening the hydrolysis step of AD. Besides, the increased VS reduction directly converted to increased methane production during the $\mathrm{AD}$ and less stabilized biosolids to be disposed of. Therefore, $\mathrm{S}_{\mathrm{VS}}$ was proportionally more important than $S_{T S}$ in terms of sludge disintegration [20, 21].

With regard to sludge mass composition, the findings of X.Feng et al. [12] showed that both TS and VS remained nearly constant during US duration. The correlation coefficients relating TS and VS to ES $\left(R_{\mathrm{TS}-\mathrm{ES}}=-0.489, R_{\mathrm{VS}-\mathrm{ES}}=0.729\right)$ further indicated that TS and VS did not depend on ES. On the contrary, the amount of soluble matters in the supernatant was strongly affected by US. The TDS increased with an increase in ES: with ES of $500-26000 \mathrm{~kJ} / \mathrm{kg} \mathrm{TS}$, the increase in TDS was $2.89-45.76 \%$ compared to untreated sludge. $\left(R_{\text {TDS-ES }}=0.987, P<0.01\right)$. Therefore, mass composition is sometimes used to evaluate the efficiency of sludge ultrasonic pretreatment.

\subsection{Dewaterability of sludge}

The aqueous phase in sludge is generally separated into two categories, free water and bound water. Whereas Kopp and Dichtl [22] and Vesilind and Martel (1989) cited by Yin et al. [23] suggested four categories: free water (not attached to sludge solids and can be separated by 
simple gravitational setting), interstitial water (trapped within the floc structure or perhaps within a cell; can be released when flocs/cells are ruptured, and removed by mechanical dewatering-devices), surface water/vicinal water (held on the surface of solid particles by adsorption and adhesion, and cannot be removed by centrifugation or other mechanical devices), and chemically bound water/water of hydration (chemically bound to the particle and can be released only by thermo-chemical destruction of particles). While Colin and Gazbar [24] defined bound water to be unfrozen water at some given temperatures (usually $-20^{\circ} \mathrm{C}$ ) and cannot be wiped off by mechanical dewatering processes, Vesilind and Hsu [25] suggested that unfrozen water included some interstitial water, all vicinal water, and all water of hydration.

\subsubsection{Positive effects of US on dewaterability of sludge}

The capillary suction time (CST) and the specific resistance to filtration (SRF) tests are both commonly used to estimate sludge dewaterability.

The enhancement level of dewaterability depends on ES, US duration, and sludge volume [26]. The CST of sludge decreased at lower $\mathrm{P}_{\mathrm{US}}$ and US duration because the flocs did not reduce their sizes, but with an increase in US duration at the same $\mathrm{P}_{\mathrm{US}}$, the CST value increased [9]. $\mathrm{Na}$ et al. [14] found that an increase in US doses (0above $2000 \mathrm{~kJ} / \mathrm{L}$ ) leaded to a decrease in CST (from 53s to under 10s), which means ultrasonic treatment of WAS improved the dewaterability. However, this result was in conflict with Feng et al. [27] who found the CST increased rapidly with ES above $2200 \mathrm{~kJ} / \mathrm{kg}_{\text {TS. The authors [27] }}$ argued that at high ES, not only floc structure was disrupted, but floc size also decreased and the EPS concentration increased, leading to the decrease in sludge dewaterability.
According to $\mathrm{Li}$ et al. [28], sludge dewaterability will increase when the degree of sludge disintegration $\mathrm{DD}_{\mathrm{COD}}(\S$ see 3.1$)$ is $2-5 \%$ because floc structure has a limited change at $\mathrm{DD}_{\mathrm{COD}}$ of less than $2 \%$, the number of fine particles in bound water increases at $\mathrm{DD}_{\mathrm{COD}}$ of 6$7 \%$, and sludge particle size significantly decreases at $\mathrm{DD}_{\mathrm{COD}}$ of more than $7 \%$.

\subsubsection{Negative effects of US on dewaterability of sludge}

Sludge dewaterability decreased gradually with an increase in US duration because a greater increase in the amount of small particles resulted in a larger surface area for holding water [11]: the SRF and CST increased from $1.67 \times 10^{12}$ $\mathrm{m} / \mathrm{kg}$ and $82 \mathrm{~s}$ of raw sludge to $1.33 \times 10^{14} \mathrm{~m} / \mathrm{kg}$ and $344 \mathrm{~s}$ of pretreated sludge, respectively after $5 \mathrm{~min}$ at $0.528 \mathrm{~W} / \mathrm{mL}$ of sonication [29]. Besides, sludge dewaterability also gradually decreased with an increase in bound water of the sludge [23] due to an increase of US density [11]: according to Chen et al. 2001 cited by Pilli [2], bound water of raw sludge was $3.8 \mathrm{~kg} / \mathrm{kg}_{\mathrm{DS}}$, and then increased to $5.9 \mathrm{~kg} / \mathrm{kg}_{\mathrm{DS}}$ and $11.7 \mathrm{~kg} / \mathrm{kg}_{\mathrm{DS}}$ at US density of $0.11 \mathrm{~W} / \mathrm{mL}$ and $0.33 \mathrm{~W} / \mathrm{mL}$, respectively. Sludge particles are disintegrated to smaller size with higher surface area causing adsorption of more water, occupying much more space in the water of sludge, preventing the transfer of water from the bottom to the top of sludge body during drying time, thus deteriorating the velocity of the release sludge water [27]. The findings of Wang et al. [29] and Dewil et al. (2006) cited by Pilli [2] indicated that ultrasonic disintegration of WAS could not improve the dewaterability, which was evidenced through the increase in both CST and SRF after US, particularly after increasing in US density and duration. However, these conclusions almost completely negate the positive effects shown above. This difference might due to the fact that

Trang 72 
these studies were not carried out with sufficient tests on low energy dosages [27].

Sludge dewaterability deteriorated with an increase in ES due to cell lysis and release of biopolymers from extracellular polymeric substances (EPS) and bacteria into aqueous phase [30]: sludge dewaterability increased in the ES range of $0-2200 \mathrm{~kJ} / \mathrm{kg}_{\mathrm{TS}}$, but it deteriorated if the ES exceeded $2200 \mathrm{~kJ} / \mathrm{kg}_{\mathrm{TS}}$, especially beyond $4400 \mathrm{~kJ} / \mathrm{kg}_{\text {TS }}$ [27]. The release of EPS in the solution increased the viscosity of the sludge [29] and created a thin layer on the surface of the filtrating membrane acting as a barrier against the water, consequently reduced WAS dewaterability (Chen et al. 2001 cited by Pilli [2]). The correlation coefficient (R) of 0.9576 [27], 0.9233 [29], or $\mathrm{R}^{2}$ of 0.9687 (Houghton et al. 2002 cited by Pilli [2]) for EPS and CST, and 0.8314 for EPS and SRF [27] have been reported. It was proved that both EPS and particle size had effects on sludge dewaterability but the former was considered more effective [27].

In addition, SRF and CST increased with the decrease in free water of the sludge, which means dewaterability had a positive correlation with free water. After US, there were two opposite effects. The first one was the transformation of interstitial water into free water because both water retained by EPS and water inside cells were released under US. The second one was an opposite trend by the adsorption effect because the decrease in size of flocs after disintegration provided more adsorbing surface on particles for water. However, the latter effect was more predominant in sludge dewatering properties, thereby sludge dewaterability deteriorated [29].

To sum up, US has both positive and negative effects on sludge dewaterability. Based on the dewaterability of pretreated sludge, the efficiency of sludge ultrasonic pretreatment can be evaluated. In general, sludge dewaterability decreases with an increase in sludge disintegration.

\subsection{Settleability of sludge}

Settling velocity (SV) is one of the most important settling parameters of sludge in routine process control and plays an important role in controlling the excess sludge emission and sludge bulking [12].

Sludge settleability changed with an increase in ES (increased after the first hour but decreased thereafter), in which the optimum ES for improving WAS settleability was $1000 \mathrm{~kJ} / \mathrm{kg}_{\mathrm{TS}}$ [12]. The SV values of pretreated sludge at ES of $500 \mathrm{~kJ} / \mathrm{kg}_{\mathrm{TS}}$ and $1000 \mathrm{~kJ} / \mathrm{kg}_{\mathrm{TS}}$ after $45 \mathrm{~min}$ were $51.62 \mathrm{~mm} / \mathrm{h}$ and $57.44 \mathrm{~mm} / \mathrm{h}$, respectively, compared to $48.44 \mathrm{~mm} / \mathrm{h}$ for the untreated sludge. At ES of more than $1000 \mathrm{~kJ} / \mathrm{kg}_{\mathrm{TS}}$, the $\mathrm{SV}$ of pretreated sludge was smaller than that of the untreated one, and gradually declined following a further increase in ES. WAS settleability was improved at ES of less than $1000 \mathrm{~kJ} / \mathrm{kg}_{\mathrm{TS}}$ because of the slight flocs disruption; on the contrary, the settleability deteriorated at ES of more than 5000 $\mathrm{kJ} / \mathrm{kg}_{\mathrm{TS}}$ [12] due to the complete breakdown of flocs and increase in EPS concentration in the liquid phase. However, Chu et al. [11] indicated that ultrasonic treatment has no effect on sludge settleability which contradicts recent research results about the changes in particle size and floc structure [12, 14].

The settleability of sludge is inversely proportional to the degree of sludge disintegration under US. This parameter is rarely individually/independently used, but usually combined with other parameters to evaluate the efficiency of sludge ultrasonic pretreatment.

\subsection{Turbidity}

The turbidity of sludge increased due to the increase in ES and particle size reduction during disintegration [13]. The supernatant turbidity of pretreated sludge decreased at ES of less than $5000 \mathrm{~kJ} / \mathrm{kg}_{\mathrm{TS}}$; particularly, the turbidity decreased 
by $27.69 \%$ and $43.52 \%$ at 500 and $1000 \mathrm{~kJ} / \mathrm{kg}_{\mathrm{TS}}$, respectively, compared to the control. However, it increased significantly at ES greater than 5000 $\mathrm{kJ} / \mathrm{kg}_{\mathrm{TS}}$ due to the release of micro-particles from sludge flocs into supernatant, which settle very slowly [12]. Therefore, the minimum ES required to disrupt sludge flocs and/or to release large amounts of organic matters was $1000 \mathrm{~kJ} / \mathrm{kg}_{\mathrm{TS}}[9$, 12].

Like the settleability of sludge, the turbidity of sludge is usually used together with other parameters to evaluate the efficiency of sludge ultrasonic pretreatment.

\subsection{Microscopic examination of sludge}

The microscopic image of microbes before and after disintegration of sludge (cellular level of the sludge disintegrated by ultrasound [31] can be used to evaluate the degree of disintegration [11] rely on the images of floc clusters' dispersion and loosening.

There are some different results from different authors. According to Dewil et al. (2006) cited by Pilli [2], US pretreatment reduces average size of flocs and creates the bulk of separate cells and short filaments pieces (Actinomyces). In addition, the flocs and cell wall will be completely broken down with the increase in US duration [11, 31]: after 60 min of sonication [11]. However, Feng et al. [12] found that even at high level of ES $\left(26000 \mathrm{~kJ} / \mathrm{kg}_{\mathrm{TS}}\right)$, neither the floc structure nor the microbial cells were totally disintegrated (because there was still a network of filamentous bacteria in the photomicrographs of the treated sludge).

It can be stated that the ultrasonication has considerable effect on microbial disruption which leads to the changes of floc density, particle size, turbidity, settling velocity, and filterability, but still unclear about the efficiency of the disruption [2].

\section{CHEMICAL CHANGE-BASED EVALUATION OF SLUDGE ULTRASONIC PRETREATMENT EFFICIENCY}

Chemical evaluation mainly focuses on sludge disintegration efficiency [3] reflected by the degree of sludge disintegration (DD $\left.D_{C O D}\right)$ parameter. Besides, the ratio of soluble COD to total COD (SCOD/TCOD) is also used because it represents the release of organic matters from solid to liquid phase after US (TCOD has not been significantly affected by US). Apart from SCOD, nucleic acids, EPS, ammonium nitrogen, and nitrate nitrogen concentrations are also considered as the important parameters in chemical evaluation after sludge sonication.

The measurement of COD in solids requires a hydrolysis step because it cannot be done directly by the COD analysis. To eliminate this step, Total organic carbon (TOC) analysis is required, in which TOC in both liquid and solid phases are measured to identify the total conversion (oxidation) of organic matters [32].

\subsection{Degree of disintegration ( $\left.\mathrm{DD}_{\mathrm{COD}}\right)$}

There are some approaches to determine the degree of sludge disintegration ( $\mathrm{DD}_{\mathrm{COD}}$ ) after US.

$\mathrm{DD}_{\mathrm{COD}}=\left[\left(\mathrm{COD}_{\mathrm{f}}-\mathrm{COD}_{\mathrm{i}}\right) /\left(\mathrm{COD}_{\mathrm{NaOH}}-\right.\right.$ $\left.\left.\mathrm{COD}_{\mathrm{NaOHo}}\right)\right] *\left[\mathrm{COD}_{\mathrm{NaOH}} / \mathrm{COD}_{\mathrm{homo}}\right] * 100(\%)$

Kunz and Wagner 1994 cited by Schmitz et al. [95]

where $-\mathrm{COD}_{\mathrm{f}}$ is the final COD of supernatant after US treatment $(\mathrm{mg} / \mathrm{L})$,

- $\mathrm{COD}_{\mathrm{i}}$ is the initial COD of supernatant (untreated) $(\mathrm{mg} / \mathrm{L})$;

- $\mathrm{COD}_{\mathrm{NaOH}}$ is the COD of supernatant at $22 \mathrm{~h}$ after addition of $1 \mathrm{M} \mathrm{NaOH}(\mathrm{mg} / \mathrm{L})$,

- $\mathrm{COD}_{\mathrm{NaOHo}}$ is the COD of supernatant just after addition of $1 \mathrm{M} \mathrm{NaOH}(\mathrm{mg} / \mathrm{L})$;

- $\mathrm{COD}_{\mathrm{NaOH}} *$ is the COD of original sample right after addition of $1 \mathrm{M} \mathrm{NaOH}(\mathrm{mg} / \mathrm{L})$;

- $\mathrm{COD}_{\text {homo }}$ is the COD of original sample after homogenization.

Trang 74 
$\mathrm{DD}_{\mathrm{COD}}=\left(\mathrm{SCOD}_{\mathrm{US}}-\mathrm{SCOD}_{0}\right) /\left(\mathrm{SCOD}_{\mathrm{NaOH}}-\right.$ $\left.\mathrm{SCOD}_{0}\right) * 100(\%)$

Muller 1996 cited by Schmitz et al. [95]

where - SCOD Us is supernatant COD of the sonicated sample $(\mathrm{mg} / \mathrm{L})$;

- $\mathrm{SCOD}_{0}$ is supernatant COD of original sample (mg/L);

- $\mathrm{SCOD}_{\mathrm{NaOH}}$ is the maximum COD release in the supernatant after $\mathrm{NaOH}$ digestion (sludge and $1 \mathrm{M} \mathrm{NaOH}$, ratio of $1: 2$ for $10 \mathrm{~min}$ at $90^{\circ} \mathrm{C}$ ).

$\mathrm{DD}_{\mathrm{COD}}=\left(\mathrm{SCOD}_{\mathrm{US}}-\mathrm{SCOD}_{0}\right) /(\mathrm{TCOD}-$ $\left.\mathrm{SCOD}_{0}\right) * 100(\%) \quad$ [56]

where $\mathrm{SCOD}_{\mathrm{Us}}$ and $\mathrm{SCOD}_{0}$ are soluble COD $(\mathrm{mg} / \mathrm{L})$ of the sonicated and the untreated sample, respectively.

$\mathrm{DD}_{\mathrm{COD}}=\left[\left(\mathrm{SCOD}_{\mathrm{US}}-\mathrm{SCOD}_{0}\right) / \mathrm{COD}_{\mathrm{Max}}\right] *$ $100(\%) \quad$ [34]

where $\mathrm{SCOD}_{\mathrm{Us}}$ and $\mathrm{SCOD}_{0}$ are soluble COD $(\mathrm{mg} / \mathrm{L})$ of the sonicated and the untreated sample, respectively; $\mathrm{COD}_{\max }$ is $\mathrm{COD}$ of the reference sample after complete chemical solubilisation with $\mathrm{H}_{2} \mathrm{SO}_{4}$.

$\mathrm{DD}_{\mathrm{COD}}$ and VS reduction were interchangeable to evaluate the efficiency of sludge ultrasonic pretreatment due to their overlaps. As mentioned, the increase in organic matters in supernatant could be correlated with VS reduction because both COD and VS represented organic matters of sludge [18].

It was proved that, sludge disintegration depends on various factors, such as (a) US frequency, (b) US intensity, (c) US duration, (d) US density, (e) specific energy input, (f) TS content, (g) temperature, (h) sludge type/properties, etc., in which (c), (e), (f), and (g) have the most significant effects on sludge disintegration [35]. During US (0-30 min of sonication), $\mathrm{DD}_{\mathrm{COD}}$ increase was almost linear with US duration, indicating the continuous and stable sludge floc disintegration: $\operatorname{DD}_{\mathbf{C O D}}(\%)=$ $1.2 \times$ US duration (min); $\mathrm{R}=0.95$ [18]. With the increase in the range of $0.1-1.5 \mathrm{~W} / \mathrm{mL}(30$ min of sonication), US density had a linear relation to $\mathrm{DD}_{\mathrm{COD}}$ : $\operatorname{DD}_{\mathrm{COD}}(\boldsymbol{\%})=\mathbf{3 8 . 7} \times$ US density $(\mathrm{W} / \mathrm{mL}) ; \mathrm{R}=0.95$ [18].

\subsection{Soluble COD assessment}

Both cellular or extracellular matter and organic debris or EPS of sludge are disintegrated by US, leading to the solubilisation of solid matters and the increase in organic matters/EPS concentrations in aqueous phase; thereby SCOD of sludge increases (SCOD increase represents sludge disintegration [18]). That is the reason why the release of those components, especially SCOD can be used as a parameter to assess sludge disintegration efficiency [13, 30, 36, 37].

The COD solubilisation $\left(\mathrm{S}_{\mathrm{COD}}\right)$ represents the transfer of COD from particulate fraction to soluble fraction of sludge, calculated by using the difference between soluble concentration (SCOD) and initial soluble concentration $\left(\mathrm{SCOD}_{0}\right)$ divided by the initial particulate concentration $\left(\mathrm{PCOD}_{0}\right)$ :

$\mathrm{S}_{\mathrm{COD}}=\left[\left(\mathrm{SCOD}-\mathrm{SCOD}_{0}\right) / \mathrm{PCOD}_{0}\right] \times 100 \%$ [19]

where COD was measured in the total sludge (T) and in the soluble fraction (S) (using the micro-method $\mathrm{HACH}$ ); $\mathrm{COD}$ of the particulate (P) was the difference between COD of $\mathrm{T}$ and $\mathrm{S}$. The soluble fraction was evaluated after centrifugation (SORVALL T $6000 \mathrm{D})$ at $3600 \times \mathrm{g}$ for $20 \mathrm{~min}$ and filtration through a $1.2 \mu \mathrm{m}$ membrane.

However, to assess the effectiveness of US, $D D_{\mathrm{COD}}$ was proven to be a better parameter than COD solubilisation: That poor COD solubilisation (10\%) corresponding to good $\operatorname{DD}_{\mathrm{COD}}(47 \%)$ demonstrated COD solubilisation was not a relevant parameter of ultrasonic efficiency [20].

\subsection{Nucleic acids assessment}

Nucleic acids are biological molecules essential for life, and include deoxyribonucleic acid (DNA) and ribonucleic acid (RNA). 
Together with proteins, nucleic acids make up the most important macromolecules. The increase in nucleic acids concentration represents cell lysis, thus they are also used to access the efficiency of sludge ultrasonic pretreatment.

With the increase in the range of $0.1-1.5$ $\mathrm{W} / \mathrm{mL}$ (30 min of sonication), US density had a linear relation to cell lysis: Nucleic acids $(\mathrm{mg} / \mathrm{L})$ $=81+523 x$ US density $(\mathrm{W} / \mathrm{mL}) ; \mathrm{R}=0.97$ [18]. Besides, cell lysis was deduced by an increase in nucleic acids following US duration (0-30 min of sonication): Nucleic acids $(\mathrm{mg} / \mathrm{L})=15+114 \mathrm{x}$ US duration ( $\mathrm{min}$ ); $\mathrm{R}=0.93$ [18].

\subsection{Protein assessment}

Proteins are important building blocks of bacteria with many different functions in the living cell (catalyze chemical and biochemical reactions in living cell and outside). It was found about $70-80 \%$ of the extracellular organic carbon contained in WAS to be in form of proteins and saccharides [38].

There are three types of protein in wastewater and sludge: soluble, bound, and tightly bound. Bound proteins are considered readily bioavailable for higher possibility of odor release. The total protein obviously declined with longer US duration while the reverse trend occurred in soluble protein. Because the cells were ruptured the cellular and extracellular proteins - known as total protein - were disintegrated, some of which were transformed into bound proteins attached to the cell while most of which were dissolved into soluble proteins. It can be inferred that the rise of soluble protein concentration helped increase the AD [39].

Under US, the activated sludge was disintegrated; consequently EPS and cellular substances were released into the aqueous phase, resulting in an increase in protein and polysaccharide levels. Therefore, protein concentration is used to evaluate the efficacy of sludge US pretreatment [29, 30]. Besides, Ca2+ and $\mathrm{Mg} 2+$ play a key role in binding the EPS, the US disintegration of sludge causes the increase in $\mathrm{Ca}^{+2}$ and $\mathrm{Mg}^{+2}$ concentrations in the aqueous phase. The increase rate was high at first but then decreased because these anions were absorbed by smaller sludge particles formed during US [30].

The coefficients of determination $\left(\mathrm{R}^{2}\right)$ for protein increase $\left(\Delta_{\text {protein }}\right), \mathrm{DD}_{\mathrm{COD} 1}$, and $\mathrm{DD}_{\mathrm{SCOD} 2}$ with reference to biogas yield ( $\left.\Delta_{\text {biogas }}\right)$ were measured to evaluate the sludge disintegration: the combined coefficients of $0.97,0.83$, and 0.54 for $\quad \Delta_{\text {protein }} / \Delta_{\text {biogas }}, \quad D_{\text {SCOD2 }} / \Delta_{\text {biogas }}, \quad$ and $\mathrm{DD}_{\mathrm{COD} 1} / \Delta_{\text {biogas }}$, respectively showed the advantage of protein-based assessment [16].

Owing to the increase in ES, proteins and polysaccharides (as well as DNA) in the supernatant initially increased with higher rate (0-20 min of US [30]): $\mathrm{R}_{\text {proteins-ES }}=0.946$, $\mathrm{R}_{\text {polysaccharides-ES }}=0.883(P<0.01)$ and an increment of $97 \%$ and $92 \%$ in proteins and polysaccharides concentrations, respectively was attained at $26,000 \mathrm{~kJ} / \mathrm{kg} \mathrm{TS}$ [12]; according to Feng et al. [27], the corresponding figures were $0.9972,0.9854,394 \%, 413 \%$, and 35,000 $\mathrm{kJ} / \mathrm{kg}_{\mathrm{TS}}$, respectively. Then the increase in proteins slowed down after longer US duration while polysaccharide and DNA concentrations dropped after $20 \mathrm{~min}$ of sonication [30]. When sludge was almost disintegrated, the dissolution of protein, DNA became slow. Besides, at higher TS content, the cavitation was decreased leading to reduction of the released protein [30].

Among those components, the level of released protein was the highest in the aqueous phase of sonicated sludge. This predominance of proteins may be due to large quantities of exoenzymes in the floc: the ratio of protein to polysaccharide was $\sim 5.4$ [12].

However, the protein measurement is not common and not yet well accepted for evaluating sludge ultrasonic disintegration efficiency. Therefore, COD measurement is usually used for

\section{Trang 76}


this purpose due to its simplicity and easiness in daily operation [2].

\section{5. $\mathrm{NH}_{3}$ assessment}

Organic nitrogen and ammonia concentrations in sludge samples increased owing to the increase in ES and TS content of WAS [3, 12, 40]. The bacterial cells were disintegrated and the intracellular organic nitrogen was released in the aqueous phase, which was subsequently hydrolyzed to ammonia, resulting in the increase in ammonia-N concentration [40]. It was important to state that the disintegration of organic nitrogen from nonbiological debris was a key factor to produce ammonia [3]. Therefore, $\mathrm{NH}_{3}$ assessment can also be considered as another method to evaluate sludge disintegration efficiency under US.

While the total nitrogen concentration $\mathrm{TN}$ (soluble + particulate concentrations) remained unchanged in sludge, the total nitrogen solubilisation hiked up owing to the increase in ES: with an increase in ES above $3600 \mathrm{~kJ} / \mathrm{kg}_{\mathrm{TS}}$, it increased linearly and reached $19.6 \%$ at 108000 $\mathrm{kJ} / \mathrm{kg}_{\mathrm{TS}}$ [20]. Total nitrogen solubilisation $\left(\mathrm{S}_{\mathrm{TN}}\right)$ was calculated by using the difference between soluble concentration (TNs) and initial soluble concentration $\left(\mathrm{TNs}_{0}\right)$ divided by the initial particulate concentration $\left(\mathrm{TNp}_{0}\right)$ :

$$
\mathrm{S}_{\mathrm{TN}}=\left[\left(\mathrm{TNs}-\mathrm{TNs}_{0}\right) / \mathrm{TNp}_{0}\right] \times 100 \% \quad[19]
$$

where TN was measured in the total sludge (T) and in the soluble fraction (S) (using the micro-method $\mathrm{HACH}$ ); TN of the particulate (P) was the difference between $\mathrm{TN}$ of $\mathrm{T}$ and $\mathrm{S}$. The soluble fraction was evaluated after centrifugation (SORVALL T $6000 \mathrm{D})$ at $3600 \times \mathrm{g}$ for $20 \mathrm{~min}$ and filtration through a $1.2 \mu \mathrm{m}$ membrane.

The correlation coefficient relating ammonium nitrogen $\left(\mathrm{NH}_{4}{ }^{+}-\mathrm{N}\right)$ to $\mathrm{ES}$ was 0.968 at the 0.01 significance level: $\mathrm{NH}_{4}{ }^{+}-\mathrm{N}$ concentration increased by $31.37 \%$ and more than $110 \%$ at ES of 500 and $11000 \mathrm{~kJ} / \mathrm{kg}_{\mathrm{TS}}$, respectively [12].
The nitrate nitrogen $\left(\mathrm{NO}_{3}{ }^{-}-\mathrm{N}\right)$ increased at $\mathrm{ES}$ of more than $5000 \mathrm{~kJ} / \mathrm{kg}_{\mathrm{TS}}(\mathrm{R}=0.946, \mathrm{P}<0.01)$. Below $1000 \mathrm{~kJ} / \mathrm{kg}_{\mathrm{TS}}, \mathrm{NO}_{3}{ }^{-} \mathrm{N}$ decreased by $16.45 \%$. In similar conditions, the increase of $\mathrm{NO}_{3}{ }^{-}-\mathrm{N}$ was much smaller than $\mathrm{NH}_{4}{ }^{+}-\mathrm{N}$ because ammonium ions were produced more easily than nitrate ions when hydroxyl radicals were generated during cavitation [12].

Table 1: Correlation analysis of ES and physical-chemical characteristics of sludge [12]

\begin{tabular}{|l|c|}
\hline \multicolumn{1}{|c|}{ Correlation } & ES \\
\hline Turbidity & $0.965^{\mathrm{a}}$ \\
\hline Particle size of dp90 & $-0.996^{\mathrm{a}}$ \\
\hline $\mathrm{TS}$ & -0.489 \\
\hline $\mathrm{VS}$ & 0.729 \\
\hline $\mathrm{TDS}$ & $0.987^{\mathrm{a}}$ \\
\hline $\mathrm{SCOD}$ & $0.993^{\mathrm{a}}$ \\
\hline $\mathrm{NH}_{4}{ }^{+}-\mathrm{N}$ & $0.968^{\mathrm{a}}$ \\
\hline $\mathrm{NO}_{3}{ }^{-}-\mathrm{N}$ & $0.946^{\mathrm{a}}$ \\
\hline Protein & $0.946^{\mathrm{a}}$ \\
\hline Polysaccharide & $0.883^{\mathrm{a}}$ \\
\hline${ }^{\mathrm{a}}$ Correlation is significant at the 0.01 level \\
\hline
\end{tabular}

In short, the release of ammonia and soluble organic nitrogen in the aqueous phase could be another useful indicator to assess the sludge disintegration efficacy under US. However, there was a requirement of correlating nitrogen release data and subsequent $\mathrm{AD}$ tests under different conditions for obtaining a standardized method to assess the sludge ultrasonic pretreatment efficiency based on NH3 data [2].

\subsection{TOC assessment}

It must be aware that TOC analysis shows all the organic carbon in the solution (solid and liquid) [32]. During US process with different

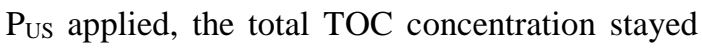
almost constant while the organics changed their status. At $200 \mathrm{~W}$, the organics were solubilised up to $11.2 \%$ and $22.8 \%$ of their total values in the solution for the industrial and municipal sludge, 
respectively. The increase in TOC in liquid phase concurred with the results obtained from the COD analysis [32].

COD tests may provide the very high solubilisation percentage of organics (but not the total solubilisation of organics). To carry out these tests to measure TCOD of the solution, it needs applying a pre-digestion (hydrolysis) method which somehow may prevent the solubilisation of all solid particles. Besides, there are also some refractory organics not oxidized by the oxidizing agent used in COD tests. Therefore, TOC tests are more accurate due to those difficulties in COD analysis. Nevertheless, COD results may be used as an indicator for exploring the solubilisation process if TOC cannot be measured [32].

\section{BIOLOGICAL CHANGE-BASED EVALUATION OF SLUDGE ULTRASONIC PRETREATMENT EFFICIENCY}

Biological properties evaluation is usually based on heterotrophic count and specific oxygen uptake rate.

The breakdown of bacterial cell walls due to US can be evaluated by biological utilization tests. The sludge microbiological activity is characterized by Oxygen Utilization/Uptake Rate (OUR). In general, sludge microbial activity decreased when $\mathrm{DD}_{\mathrm{COD}}$ increased during ultrasonic sludge treatment. When $\mathrm{DD}_{\mathrm{COD}}$ was 0 $20 \%$, microbial activity was enhanced and OUR increased by about $20-40 \%$ indicating the predominant influence of floc structure change at this stage. OUR still increased but less than $20 \%$ when $\mathrm{DD}_{\mathrm{COD}}$ was $20-40 \%$, which meant that some microorganisms were damaged. When $\mathrm{DD}_{\mathrm{COD}}$ was over $40 \%$, most bacteria were disrupted at different degrees, and sludge microbial activity decreased significantly. In other words, cells started to lyse only when $\mathrm{DD}_{\mathrm{COD}}$ was over $40 \%$ [28]. The survival ratio (ratio of viable bacteria density levels after US to those of original sample) of the heterotrophic bacteria decreased owing to the increase in US duration [11]. Therefore, in some researches, OUR measurement can be used to evaluate the sludge disintegration efficiency with respect to US.

The change of sludge microbial activity

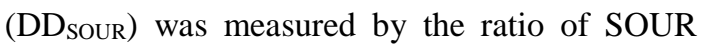
change to the initial value:

$\mathrm{DD}_{\text {SOUR }}=\left(\mathrm{SOUR}-\mathrm{SOUR}_{0}\right) / \mathrm{SOUR}_{0} * 100 \%$ [28]

where SOUR and SOUR 0 are values of treated and untreated sludge samples, respectively:

An approximate relation between $\mathrm{DD}_{\text {Sour }}$ and $\mathrm{DD}_{\mathrm{COD}}$ was evaluated and expressed as followed equation, which can be used only when $\mathrm{DD}_{\mathrm{COD}}$ is over $1 \%$ :

$\mathrm{DD}_{\text {SOUR }}=-3.75 \mathrm{DD}_{\mathrm{COD}}{ }^{2}+0.75 \mathrm{DD}_{\mathrm{COD}}+$ $0.21 ; \mathrm{R}=0.9330$ [28].

However, there was a big difference between sludge OUR decrease (the sludge inactivation efficiency, 95.5\%) and $\mathrm{DD}_{\mathrm{COD}}(30.1 \%)$, which indicated that some chemical reactions might have happened and inhibited cell metabolisms without disrupting the sludge structure [18]. Besides, microbes were inactivated well prior to their disintegration [40]: the percentage of microbial inactivation ranged from $53 \%$ to $69 \%$ (corresponding to different TS contents) after 60s of US and the OUR values changed insignificantly at longer duration. Therefore, OUR data should not be used to judge the degree of sludge disintegration [2].

DD $D_{\text {OUR }}$ is considered as the degree of inactivation and calculated as follows:

$\operatorname{DD}_{\text {OUR }}(\%)=\left[1-\right.$ OUR$\left./ O U R_{0}\right] \times 100$ [36]

where OUR and $\mathrm{OUR}_{0}$ is the oxygen uptake rate of sonicated and original sample, respectively. In this case, $\mathrm{DD}_{\text {OUR }}$ was directly proportional to $\mathrm{DD}_{\mathrm{COD}}$. The DD $\mathrm{D}_{\mathrm{OUR}}$ increased quickly with the increase in $\mathrm{ES}$ up to $40 \mathrm{~kJ} / \mathrm{g}_{\mathrm{TS}}$; 
beyond this value will slow down the $\mathrm{DD}_{\text {OuR }}$ increase rate [36].

Low US densities $(0.05 \mathrm{~W} / \mathrm{mL}, 0.1 \mathrm{~W} / \mathrm{mL}$, and $0.2 \mathrm{~W} / \mathrm{mL}$ ) led to the initial increase in SOUR, stimulating microbial activity, and a slight increase in SCOD. This indicated that US with low density could only disrupt slightly the floc but the cell lysis did not occur (microorganisms were not destroyed). In other words, the microbial activity would go up when the micro-floc aggregates were separated from the sludge flocs [28].

Following the increase in ES, the OUR increased and reached the optimum; beyond this value of ES, the OUR decreased exponentially because of inactivation of microbes (Most bacteria were disrupted and sludge microbial activity decreased drastically) $[11,28]$.

Chu et al. [11] suggested the hypothesis as follows: There were multiple stages existing in the sonication of biological sludge. In the first stage (0-20 min), mechanical forces broke down the porous flocs into small particles and released extracellular polymers. In the second stage (20$60 \mathrm{~min}$ ), the biomass was inactivated and organic matters were dissolved. In the final stage $(>60$ $\min$ ), sonication had essentially no effect on the sludge if the bulk temperature has been controlled (floc would be completely destroyed after $60 \mathrm{~min}$ of sonication); if the bulk temperature of sludge was not controlled, the total coliform could be disinfected effectively as time exceeded $60 \mathrm{~min}$ [11].

Zhang et al. [18] showed that the sludge inactivation efficiency increased significantly after $10 \mathrm{~min}$ of sonication and the biomass inactivation stage was $10-30 \mathrm{~min}$, which was different from Chu et al. [11] due to the different US density applied $(0.3 \mathrm{~W} / \mathrm{ml}$ in [11] vs. 0.5 $\mathrm{W} / \mathrm{ml}$ in [18]). After $30 \mathrm{~min}$ of sonication, the sludge OUR decrease ratio was $95.5 \%$, which indicated that biological cells were almost completely inactivated. Therefore, the hypothesis mentioned above was modified as follows: sludge disintegration and cell lysis occurred continuously during sonication but sludge inactivation occurred mainly in the second stage (10-30 min) [18]. Inactivation of sludge (biomass inactivation) depends on US duration. It occurred after 10 min of sonication [18] and after 20 min of sonication using low US density [11], which indicated that US density is also a parameter affecting on inactivation of sludge.

Besides, Li et al. [28] indicated two main stages of ultrasonic sludge pretreatment process: (i) sludge flocs were changed and disintegrated at first, and then (ii) the exposed cells were disrupted. In the first stage, some organic matters contained in the flocs were dissolved and SCOD increased slightly. At the same time, SOUR was increased due to the enhancement of oxygen and nutrients consumption. In the second stage, some cells were exposed and damaged by ultrasonic cavitation, leading to the release in intracellular organic matters, the further increase in SCOD, and the significant decrease in SOUR. Due to the heterogeneity of sludge and the differences in the external resistances of many types of zoogloea and bacteria, activation and inactivation took effects at the same time and the comprehensive effectiveness was under the influence of various ultrasonic parameters.

\section{CONCLUSIONS}

Ultrasonic irradiation is a feasible and promisingly applicable mechanical disruption technique for sludge disintegration. Because many processing factors significantly affect cavitation and consequently the efficiency of sludge pretreatment, assessment and selection of optimal ultrasonic conditions for actual application of sludge pretreatment are sorely necessary. An extensive review of evaluation approaches of sludge ultrasonic pretreatment 
efficiency was presented with regard to changes in:

- Physical properties: particle size, sludge mass reduction and mass composition, dewaterability, settleability, turbidity, and microscopic examination.

- Chemical properties: increase in SCOD, nucleic acids, proteins, polysaccharides, nitrate nitrogen, release of $\mathrm{NH}_{3}$, TOC...

- Biological properties: heterotrophic count and specific oxygen uptake rate.

Currently, experts in this field have not had common consent the methods of evaluating the efficiency of sludge ultrasonic pretreatment. Different authors have expressed the effect of US on sludge disintegration in different reference parameters. There is still no comprehensive method to evaluate the efficiency of sludge ultrasonic pretreatment. However, some main parameters which have been commonly used for this purpose are $\mathrm{DD}_{\mathrm{COD}}$, proteins, specific oxygen uptake rate, particle size reduction... due to their simplicity, easiness, and predominant accuracy in daily operation.

\section{Các cách tiếp cận để đánh giá hiệu quả tiền xử lý bùn thải bằng công nghệ siêu âm}

- Lê Ngọc Tuấn

Trường Đại học Khoa học Tự nhiên, ĐHQG-HCM

- Phạm Ngọc Châu

Đại học Bangkok - Thái Lan

\section{TÓM TÁT:}

Siêu âm được xem là công nghệ cơ học khả thi và tiềm năng cho việc phân rã bùn thải, thúc đẩy phân hủy sinh học và tăng cường tiêu hóa ky khí. Các nghiên cứu cho thấy có rất nhiều yếu tố ảnh hưởng đáng kể đến cavitation và theo đó là hiệu quả tiền xử lý bùn thải. Vì vậy, đánh giá, so sánh và lựa chọn các điều kiện siêu âm tối ưu - hướng đến ứng dụng thực tế cho việc tiền xử lý bùn thải - là vô cùng cần thiết. Bài báo trình bày tổng quan các cách tiếp cận để đánh giá hiệu quả tiền xử lý bùn thải bằng công nghệ siêu âm dựa trên tính chất vật lý, hóa học và sinh học của bùn sau xử lý.

Từ khóa: Đánh giá các biến đổi sinh học, Đánh giá các biến đổi hóa học, Đánh giá các biến đổi vật lý, tiền xử lý bằng siêu âm, bùn thải thứ cấp. 


\section{REFERENCES}

[1]. H. Carrère, C. Dumas, A. Battimelli, D.J. Batstone, J.P. Delgenès, J.P. Steyer, I. Ferrer, Pretreatment methods to improve sludge anaerobic degradability: A review, Journal of Hazardous Materials 183 (2010) $1-15$

[2]. Sridhar Pilli, Puspendu Bhunia, Song Yan, R.J. LeBlanc, R.D. Tyagi, R.Y. Surampalli, Ultrasonic pretreatment of sludge: A review, Ultrasonics Sonochemistry 18 (2011) 1-18

[3]. S.K. Khanal, D. Grewell, S. Sung, J. Van Leeuwen, Ultrasound applications in wastewater sludge pretreatment: A review, Crit. Rev. Environ. Sci. Technol. 37 (2007) 277-313.

[4]. W.P. Barber, The effects of ultrasound on sludge digestion, J. Chart. Inst. Water Environ. Manage. 19 (2005) 2-7.

[5]. T.I. Onyeche, O. Schlafer, H. Bormann, C. Schroder, M. Sievers, Ultrasonic cell disruption of stabilised sludge with subsequent anaerobic digestion, Ultrasonics 40 (2002) 31-35.

[6]. T. Mao, S.Y. Hong, K.Y. Show, J.H. Tay, D.J. Lee, A comparison of ultrasound treatment on primary and secondary sludges, Water Sci. Technol. 50 (2004) 9197.

[7]. A. Tiehm, K. Nickel, U. Neis, The use of ultrasound to accelerate the anaerobic digestion of sewage sludge, Water Sci. Technol. 36 (1997) 121-128

[8]. K.Y. Show, T. Mao, D.J. Lee, Optimization of sludge disruption by sonication, Water Res. 41 (2007) 4741-4747.

[9]. Gonze E., Pillot S., Valette E., Gonthier Y. and Bernis A. Ultrasonic treatment of an aerobic sludge in batch reactor. Chemical
Engineering and Processing, 42 (2003), 965-975.

[10]. Le Ngoc Tuan, Ratsimba B., JulcourLebigue C. and Delmas H. Effect of external pressure on the efficacy of ultrasonic pretreatment of sludge, International Proceedings of Chemical, Biological and Environmental Engineering, 42 (2012), 86-94.

[11]. C.P. Chu, B.V. Chang, G.S. Liao, D.S. Jean, D.J. Lee, Observations on changes in ultrasonically treated waste-activated sludge, Water Res. 35 (2001) 1038-1046.

[12]. X. Feng, H.Y. Lei, J.C. Deng, Q. Yu, H.L. Li, Physical and chemical characteristics of waste activated sludge treated ultrasonically, Chem. Eng. Process. 48 (2009) 187-194 (Process Intensification).

[13]. A. Tiehm, K. Nickel, M.M. Zellhorn, U. Neis, Ultrasound waste activated sludge disintegration for improving anaerobic stabilization, Water Res. 35 (2001) 20032009.

[14]. S. Na, Y.U. Kim, J. Khim, Physiochemical properties of digested sewage sludge with ultrasonic treatment, Ultrason. Sonochem. 14 (2007) 281-285.

[15]. Jorand, F., Zartarian, F., Thomas, F., Block, J. C., and Bottero, J. Y. Chemical and structural linkage between bacteria within activated sludge flocs. Water Res., 29(6) (1995), 1639-1647.

[16]. B. Akin, S.K. Khanal, S. Sung, D. Grewell, J. Van-Leeuwen, Ultrasound pre-treatment of waste activated sludge, Water Sci. Technol. 6 (2006) 35-42.

[17]. Dogan, Combination of Alkaline solubilisation with microwave digestion as a sludge disintegration method: effect on gas production and quantity and dewater- 
ability of anaerobically digested sludge, A thesis of Master Degree, 2008

[18]. P. Zhang, G. Zhang, W. Wang, Ultrasonic treatment of biologic sludge: floc disintegration, cell lysis and inactivation, Bioresour. Technol. 98 (2007) 207-210.

[19]. Bougrier C. , Albasi C., Delgenes J.P., Carrere H., Effect of ultrasonic, thermal and ozone pre-treatments on waste activated sludge solubilisation and anaerobic biodegradability. Chemical Engineering and Processing 45 (2006), 711-718

[20]. M.R. Salsabil, A. Prorot, M. Casellas, C. Dagot, Pre-treatment of activated sludge: effect of sonication on aerobic and anaerobic digestibility, Chem. Eng. J. 148 (2009) 327-335.

[21]. G. Erden and A. Filibeli, Ultrasonic pretreatment of biological sludge: consequences for disintegration, anaerobic biodegradability, and filterability, Research Article, 2009.

[22]. J. Kopp and N. Dichtl, Influence of the free water content on the dewaterability of sewage sludges, Water Science \& Technology Vol 44 No 10 (2001), 177183, IWA Publishing

[23]. Xuan Yin, Pingfang Han, Xiaoping Lu, Yanru Wang, A review on the dewaterability of bio-sludge and ultrasound pre-treatment, Ultrasonics Sonochemistry 11 (2004) 337-348

[24]. F. Colin, S. Gazbar, Distribution of water in sludges in relation to their mechanical dewatering, Water Res. 29 (8) (1995) 2000-2005.

[25]. P.A. Vesilind, C.-C. Hsu, Limits of sludge dewaterability, Water Sci. Technol. 36 (11) (1997) 87-91.

[26]. J. Kim, C. Park, T.H. Kim, M. Lee, S. Kim, S.W. Kim, J. Lee, Effects of various pre- treatments for enhanced anaerobic digestion with waste activated sludge, J. Biosci. Bioeng. 95 (3) (2003) 271-275.

[27]. X. Feng, J. Deng, H. Lei, T. Bai, Q. Fan, L. Zhaoxu, Dewaterability of waste activated sludge with ultrasound conditioning, Bioresour. Technol. 100 (2009) 1074-1081.

[28]. L. Huan, J. Yiying, R.B. Mahar, W. Zhiyu, N. Yongfeng, Effects of ultrasonic disintegration on sludge microbial activity and dewaterability, J. Hazard. Mater. 161 (2009) 1421-1426.

[29]. F. Wang, M. Ji, S. Lu, Influence of ultrasonic disintegration on the dewaterability of waste activated sludge, Environ. Prog. 25 (2006) 257-260.

[30]. F. Wang, S. Lu, M. Ji, Components of released liquid from ultrasonic waste activated sludge disintegration, Ultrason. Sonochem. 13 (2006) 334-338.

[31]. S.K. Khanal, H. Isik, S. Sung, J. Avan Leeuwen, Ultrasonic conditioning of waste activated sludge for enhanced aerobic digestion, Proceedings of IWA Specialized Conference - Sustainable Sludge Management: State of the Art,Challenges and Perspectives, May 29-31, Moscow, Russia, 2006.

[32]. Rana Kidak, Anne-Marie Wilhelm, Henri Delmas, Effect of process parameters on the energy requirement in ultrasonical treatment of waste sludge, Chemical Engineering and Processing 48 (2009) 1346-1352

[33]. U. Schmitz, C.R. Berger, H. Orth, Protein analysis as a simple method for the quantitative assessment of sewage sludge disintegration, Water Res. 34 (2000) 36823685 .

[34]. C. M. Braguglia, G. Mininni, A. Gianico, Is sonication effective to improve biogas production and solids reduction in excess

\section{Trang 82}


sludge digestion?, Water Sci. Technol. 57 (4) (2008) 479-483.

[35]. A. Gronroos, H. Kyllonen, K. Korpijarvi, P. Pirkonen, T. Paavola, J. Jokela, J. Rintala, Ultrasound assisted method to increase soluble chemical oxygen demand (SCOD) of sewage sludge for digestion, Ultrason. Sonochem. 12 (2005) 115-120.

[36]. C.L. Rai, G. Struenkmann, J. Mueller, P.G. Rao, Influence of ultrasonic disintegration on sludge growth and its estimation by respirometry, Environ. Sci. Technol. 38 (2004) 5779-5785.

[37]. K. Nickel, U. Neis, Ultrasonic disintegration of biosolids for improved biodegradation, Ultrason. Sonochem. 14 (2007) 450-455.

[38]. Neyens E., Baeyens J., Dewil R., Bart De heyder 2004, Advanced sludge treatment affects extracellular polymericsubstances to improve activated sludge dewatering, Journal of Hazardous Materials 106B (2004) 83-92

[39]. Madhumita Ray, Saad Aldin, Sayed Elbeshbishy, Fuzhou Tu, George Nakhla, Pre-treatment of Primary Sludge Prior to Anaerobic Digestion

[40]. B. Akin, Waste activated sludge disintegration in an ultrasonic batch reactor, Clean - Soil, Air, Water 36 (2008) 360-365. 